\title{
Blood transfusion: safety, optimisation and new advances
}

\section{Shubha Allard}

Consultant Haematologist, Barts Health NHS Trust and NHS Blood and Transplant, London, UK

\section{Oral presentation}

Oral presentation is available online

\footnotetext{
Correspondence: Shubha Allard

(C) Copyright S. Allard, 2013

Licensee PAGEPress, Italy

Thalassemia Reports 2013; 3(s1):e23

doi:10.4081/thal.2013.s1.e23

This article is distributed under the terms of the Creative Commons Attribution Noncommercial License (by-nc 3.0) which permits any noncommercial use, distribution, and reproduction in any medium, provided the original author(s) and source are credited.

Parts of this work were presented at the

"3rd Pan-European Conference on Haemoglobinopathies and Rare Anaemias", Limassol (Cyprus), 24-26 October 2012.
} 